\title{
Clinical and Surgical Experience in the Management of Cardiac Myxomas: The Early and Mid-Term Results
}

\author{
Kardiyak Miksomaların Tedavisinde Klinik ve Cerrahi Deneyimimiz: Erken ve Orta Dönem Sonuçlar \\ Hafize Yalınız', Uğur Göçen'1, Atakan Atalay', Şerafettin Demir², Vecih Keklik¹, Orhan Kemal Salih', \\ Mehmet Şah Topçuoğlu', Hakan Poyrazoğlu' ${ }^{1}$, Yasin Güzel ${ }^{1}$ \\ ${ }^{1}$ Department of Cardiovascular Surgery, Faculty of Medicine, Cukurova University, Adana, Turkey \\ ${ }^{2}$ Department of Cardiology, Adana Public Hospital, Adana, Turkey
}

\section{ABSTRACT}

Objective: Cardiac myxoma is the most common benign heart tumor. In this study, early and mid-term results of patients who underwent intracardiac myxoma exicision surgery were examined.

Methods: Between to 1988 and 2012 years, 31 patients with a median age of 56 years (range, 33 to 78 years) were operated for myxoma. Eighteen female and 13 male underwent surgical excision of primary intracardiac myxomas. Twelve patients (38.7\%) presented with congestive heart failure symptoms and 19 patients (61.3\%) with mitral obstruction symptoms. Preoperative diagnosis was established by transthoracic two dimensional echocardiography. Nineteen had right atrial (RA) myxomas, 12 patients had left atrial (LA) myxoma. The surgical management was performed by wide excision under cardiopulmonary bypass.

Results: One patient with cerebral embolism died during the early postoperative period. Mean follow-up was $9.8 \pm 1.4$ years. Thirty patients had on regular follow-up in NYHA Class I symptoms with no documented recurrences.

Conclusions: All patients with cardiac myxoma have immediate surgical treatement indication. Surgical excision of atrial myxoma gives excellent short and mid-term results. (JAREM 2013; 3: 84-7)

Key Words: Myxoma, transthoracic echocardiography, surgery, excision

\section{ÖZET}

Amaç: Kardiyak miksoma en sık görülen iyi huylu kalp tümörleridir. Bu çalışmada, eksizyon cerrahisi yapılan intrakardiyak miksomalı hastaların erken ve orta dönem sonuçları değerlendirilmiştir.

Yöntemler: Miksoma nedeni ile 1988 ve 2012 yılları arasında opere edilen, ortalama yaşı 56 olan (yaş aralığı 33-78) 31 hasta değerlendirildi. Hastaların 18'i kadın, 13'ü erkek idi. On iki hastada $(\% 38,7)$ konjestif kalp yetmezliği ve 19 hastada $(\% 61,3)$ mitral obstruksiyon semptomları mevcuttu. Operasyon öncesi tanı transtorasik 2 boyutlu ekokardiyografi ile kondu. On dokuz hastada sağ atrial mixoma,12 hastada sol atriyal miksoma mevcuttu. Cerrahi tedavide kardiyopulmoner bypass altında geniş eksizyon uygulandı.

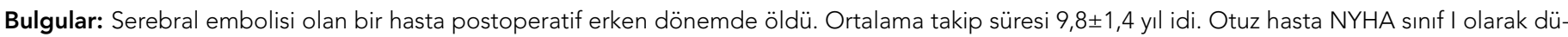
zenli olarak takip edilmiş ve hastalarda nüks görülmemiştir.

Sonuç: Miksomalı tüm hastalarda hemen cerrahi tedavi indikasyonu vardır. Atrial miksomanın cerrahi eksizyonunun erken ve orta dönem sonuçları mükemmeldir. (JAREM 2013; 3: 84-7)

Anahtar Sözcükler: Miksoma, transtorasik ekokardiyografi, cerrahi, eksizyon

\section{INTRODUCTION}

Intracardiac myxoma is the most common tumor of the heart with an estimated incidence of 0.5 cases per million people per year and composes approximately $70 \%$ of all cardiac tumors (1). Approximately $75 \%$ of these tumors arise from left atrium (LA) and 5-20\%from the right atrium (RA), 5\% from both atria or the ventricle (2). With the improvement of new diagnostic modalities, especially two-dimensional echocardiography, the diagnosis has been easier and less hazardous. In 1954, Crawford successfully excised a myxoma from the left atrium using cardiopulmonary bypass (3). Surgical intervention offers a potential for cure. The aim of this study was to review the presentation, treatment, and prognosis of atrial myxomas and review the early and late results outcome after myxoma excision.

Address for Correspondence / Yazışma Adresi: Dr. Hafize Yalınız Department of Cardiovascular Surgery, Faculty of Medicine, Çukurova University, Adana, Turkey

Phone.: +903223386815 E-mail: hafize101@yahoo.com

\section{METHODS}

\section{Study Setting and Design}

The study was designed as a retrospective observational case study. From February 1988 to December 2012, 31 consecutive patients surgically treated for intracardiac myxomas in our center were studied.

\section{Patients and Study Evaluations}

Eighteen (58.1\%) were female and 13 patients (41.9\%) were male, and the median age was 56 years (range. from 33 to 78 years) (Table 1). There were 12 LA myxomas (38.7\%), 19 RA myxomas (61.2\%). All patients with RA myxoma presented with features of right heart failure and all patients with LA myxoma mimicked mitral stenosis clinically. One patient with LA myxoma (3.2\%) was admitted to the Emergency Department with a history of sudden 
Table 1. Clinical characteristics of the myxoma patients (n: 31 cases)

\begin{tabular}{|c|c|}
\hline Variable & Number of patients $(n=31)$ \\
\hline $\begin{array}{l}\text { Sex } \\
\text { Female/Male }\end{array}$ & $18 / 13$ \\
\hline $\begin{array}{l}\text { Symptoms } \\
\text { Congestive Heart Failure,\% } \\
\text { Dyspnea, \% } \\
\text { Palpitation, \% } \\
\text { Chest Pain, \% }\end{array}$ & $\begin{array}{l}12(30.8 \%) \\
31(100 \%) \\
31(100 \%) \\
31(100 \%)\end{array}$ \\
\hline $\begin{array}{l}\text { Preoperative rhythm } \\
\text { Sinus, \% } \\
\text { Atrial fibrillation, \% }\end{array}$ & $\begin{array}{l}31(100 \%) \\
0\end{array}$ \\
\hline $\begin{array}{l}\text { Emboli } \\
\text { Central nervous system, \% } \\
\text { Peripheral, \% }\end{array}$ & $\begin{array}{l}1(30.2 \%) \\
0\end{array}$ \\
\hline
\end{tabular}

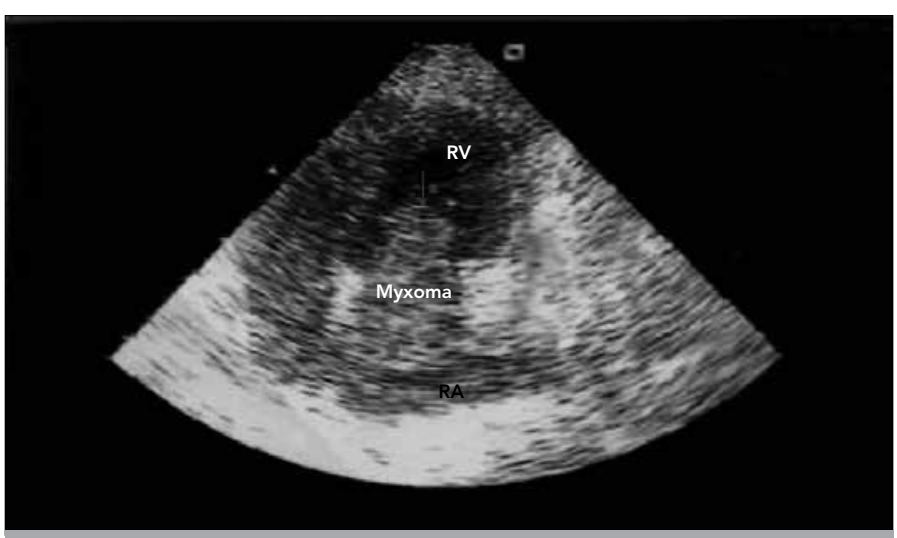

Figure 1. Transthoracic two-dimensional echocardiyography: The mass apical for chamber view showing the right atrial myxoma (arrows) RV: Right ventricle, RA: Right atrium

onset weakness of both lower limbs and abnormal movement of the upper limb one day prior to admission. On neurological examination, he had findings of cerebral stroke. On physical examination, he had mitral obstructive symptoms. The clinical profile of the patient is shown in Table 1. Preoperative diagnosis was established in all patients by transthoracic two-dimensional (2D) echocardiography (TTE) (Figure 1). Tumor location was revealed in the right atrium of 19 patients, and the tumors were attached to the interatrial septum and measurements were in the range of $40-55 \mathrm{~mm} \times 60-90 \mathrm{~mm}$. Tumor location was revealed in the LA of 12 patients and measured $(85-100 \mathrm{~mm} \times 55-60 \mathrm{~mm})$, a large homogenous tumor attached to the atrial septum, which was prolapsing into the left ventricle during diastole. Mild mitral regurgitation was noted. The diastolic gradient across the mitral valve was significant. None of the patients underwentcardiac catheterization for diagnosis. A summary of the operative findings and surgical techniques is shown in Table 2. All patients were operated on after the diagnosis of atrial myxoma was made. The operation, performed under cardiopulmonary bypass, used aortic bicaval cannulation, moderate hypothermia and antegrade blood cardioplegia. We did not manipulate the tumor before the aorta was cross clamped. The transseptal approach incision was used for the surgery. The tumor was widely excised with the
Table 2. Myxomas: Operative finding and surgical techniques

\begin{tabular}{|c|c|c|}
\hline Myxoma & $\begin{array}{c}\text { RA myxomas } \\
(n: 19)\end{array}$ & $\begin{array}{l}\text { LA Myxoma } \\
(n: 12)\end{array}$ \\
\hline $\begin{array}{l}\text { Approach } \\
\text { Transseptal approach like } \\
\text { biatrial incision }\end{array}$ & 19 (100\%) & 12 (100\%) \\
\hline $\begin{array}{l}\text { Location } \\
\text { Interatrial septum } \\
\text { Tricuspid valve leaflet }\end{array}$ & $\begin{array}{l}17(89.4 \%) \\
2(10.5 \%)\end{array}$ & 12 (100\%) \\
\hline $\begin{array}{l}\text { Appearance } \\
\text { Gelatinous and lobulated } \\
\text { Peduncle }\end{array}$ & $\begin{array}{l}19(100 \%) \\
19(100 \%)\end{array}$ & $\begin{array}{l}12(100 \%) \\
12(100 \%)\end{array}$ \\
\hline $\begin{array}{l}\text { Closure of the defect } \\
\text { Direct } \\
\text { Patch }\end{array}$ & $\begin{array}{c}8(42.1 \%) \\
11(57.9 \%)\end{array}$ & $\begin{array}{l}9(75 \%) \\
3(25 \%)\end{array}$ \\
\hline
\end{tabular}

base on the septum (Figure 2). All four chambers were washed with cold saline and any loose tumor fragments eliminated. The surgically created atrial septal defect was repaired directly in 17 patients (54.8\%) and with a bovine pericardial patch in 14 patients (45.1\%). The external appearance of tumors was usually gelatinous. The tumors ranged in size from a peduncle of $6 \times 3 \times 7 \mathrm{~cm}$ to $5,5 \times 7 \times 9 \mathrm{~cm}$ (Figure $3 a, b)$. All the myxomas were subjected to routine histopatological examination and the diagnosis of myxoma confirmed.

\section{Statistical Analyses}

Quantitative data was given as mean \pm Standard Deviation. Qualitative values were described by percentages.

\section{RESULTS}

The hospital mortality after excision of myxomas was $3.2 \%$ ( one patient with left atrial myxoma). This patient died due to a sudden malignant arrhythmia during the early postoperative period. The other 30 patients were followed up on an outpatients basis at regular intervals. They underwent clinical examination, rontgenography, electrocardiography and TTE. Mean follow-up was $9.8 \pm 1.4$ years. There were no recurrence of myxoma and all patients' cardiac symptoms were classified in NYHA Class I.

\section{DISCUSSION}

Cardiac myxomas are benign intracavitary neoplasms with an incidence between 0.0013 and $0.03 \%$ in cardiac surgery $(4,5)$. Cardiac myxomas may be localized in any of the four cardiac chamber. They are more common in the atrial chambers, especially in the LA(2), usually appear in middle age, and are more frequent in women. In our study, patients were mostly female and middle-aged similar to other studies. However, the localization of tumor were mostly in the right atrium, contrary to the other studies. This revealed similar incidences, and as in other series, a female predominance was noted with a female: male ratio of $1.4-2 / 1$. The mean age of our patients was 46.7 years, which is in concordance with that from the literature (6-9). Clinical symptoms of myxomas were atypical and quite variable. The clinical mani- 
festations of myxomas depend on localization, size and speed of growth of the myxoma $(8,10)$. All patients with LA myxomas presented with mitral obstructive symptoms. One patient with an LA myxoma presented with cerebral embolisation (stroke) and mitral obstructive symptoms preoperatively. All patients with RA myxomas presented with symptoms of congestive cardiac failure. Two-dimensional (2D) TTE is a safe and currently the most important diagnostic modality available for imaging cardiac tumors (11). Transesophageal echocardiography has increased the specificity and sensitivity of diagnosis, especially in patients who have a poor transthoracic echocardiographic window. Coronary angiography should be performed in older patients who are at risk for coronary artery disease. In our series, echocardiography was uniformly successful in diagnosis of the tumor. None of the patients required coronary angiography. Surgical excision of cardiac myxomas must be performed, as soon as possible after the diagnosis is established because of the high risk of valvular obstruction or systematic/pulmonary embolisation. The reported rate of left or right sided embolic phenomena associated with cardiac myxomas varies. There is a slight difference in the reported rates of embolism of left and right sided myxomas with

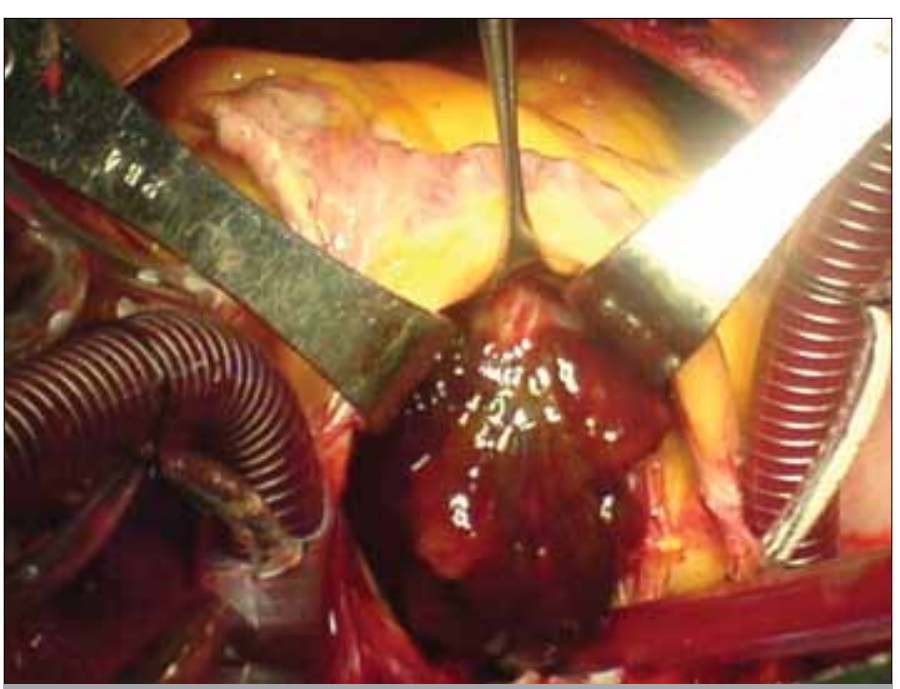

Figure 2. Showing a large myxoma situated within the left atrium (LA)

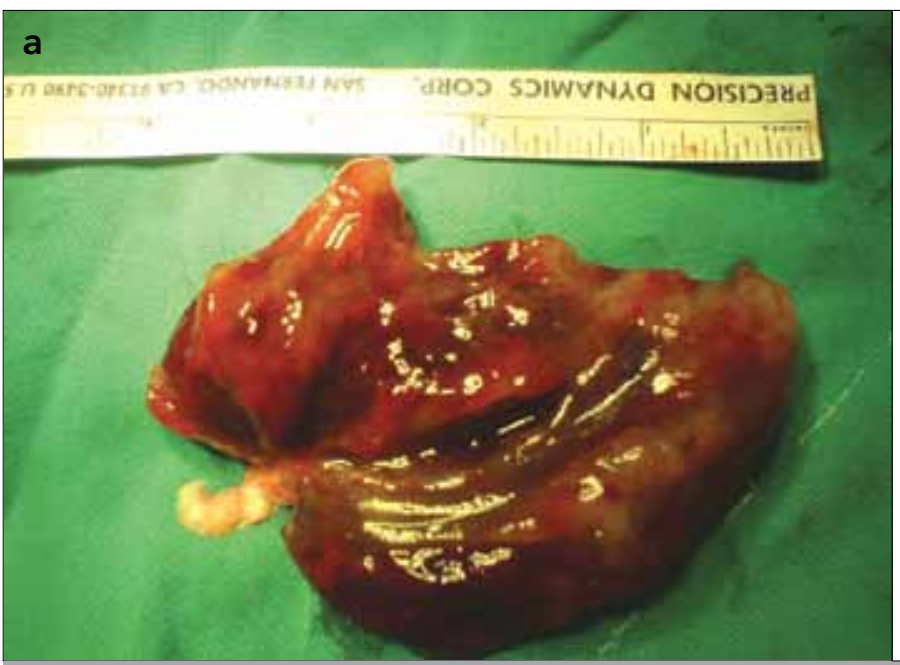

systemic emboli occurring in 30-45\% of patients with left sided cardiac myxoma and pulmonary embolism occurring in about $10 \%$ of patients found to have right sided cardiac myxoma (6). In right sided myxomas, multiple embolisms can give rise to pulmonary hypertension. Rarely, this can give rise to fatal pulmonary obstruction (6). According to researchers, symptoms associated with embolic phenomena such as stroke or transient ischemic attack are more common in young adults (1 in 250) than in older patients with these problems ( 1 in 750) (1). Our patient with cerebral embolism was 36-year-old.

Surgical techniques for treating atrial myxoma are median sternotomy under total CPB or minimally - invasive videoassisted approaches. Tumor fragmentation, followed by embolisation of myxomatous debris, can be a serious intraoperative complication of this procedure. However, the risk of embolisation can be greatly reduced, by manipulating the heart as little as possible during cannulation and tumor excision (12). Various surgical approaches have been reported in the literature $(6,13-16)$. The RA and RV myxomas are approached through the right atrium. RA myxomas demand more care during cannulation (6). The LA approach gives a direct and fast access to the myxoma though not to its attachment (13). The biatrial approach also allows good exploration of all the cardiac chambers $(14,15)$. The transseptal approach through right atriotomy suggested by Chit wood is more practical and conservative (16). It has been estimated that cardiac myxomas recur in 3\%-7\% of cases (17-20). McCarthy et al. (18) classified cardiac myxomas into three types: complex, familial and sporadic. Patients with complex and familial myxomas are characterized by a high incidence of recurrent myxomas (19). Therefore, careful surgical management and postoperative follow-up are important for these patients. The incidence of recurrence after complete excision is $1 \%-3 \%$ in patients with sporadic myxomas and thus a continuous postoperative follow-up is called for (19). Gerbode was the first to report recurrence (20). Recurrence can be due to inadequate resection, intraoperative implantation, embolization, or tumor seeding at the time of operation, and multiple foci of the tumor $(17,18,20)$. Recurrence may occur within a few months to several years after the initial surgical excision and most are found in the first four years. In these cases, again, a wide resec-

\section{b}

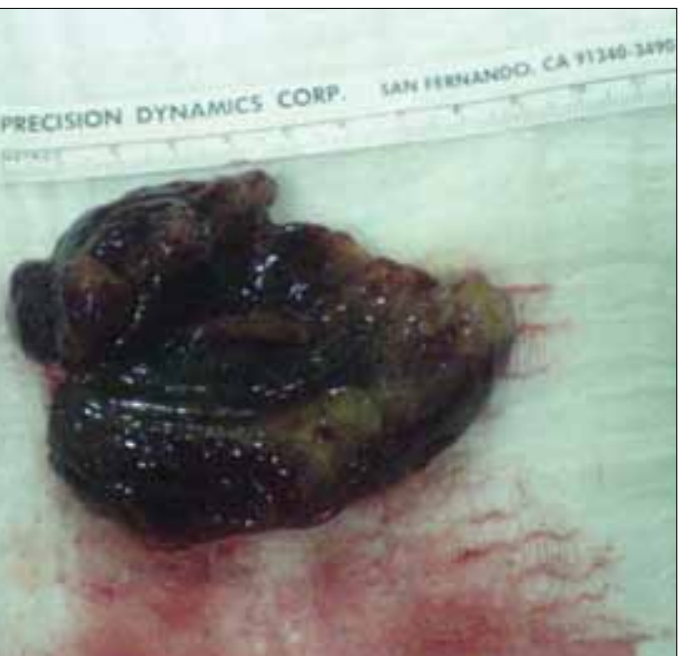

Figure 3. a) Showing a lobular, gelatinous, peduncular myxoma that caused cerebral emboli. b) Showing a lobular, gelatinous myxoma 
tion of the atrial septum is recommended. Therefore, resections should be complete, including all of the pedicle and the attachment area, plus a safety margin $(10,15)$. In our experience, the transseptal approach, like a biatrial incision, also allows good exposure, ease and wide resection, and visualization of all the cardiac chambers for any concomitant tumor. All of our patient myxomas were sporadic and we did not see any recurrences.

\section{CONCLUSION}

Cardiac myxomas have a variety of symptoms and signs. Obstructive symptoms are the common mode of presentation, followed by embolic manifestation. Immediate surgical treatment is indicated in all patients. The transseptal approach like a biatrial incision should be applied. Complete excision of the tumor with excision of the tissue surrounding the pedicle including endocardium is sufficient, and gives excellent early and mid-term results.

\section{Conflict of Interest}

No conflict of interest was declared by the authors.

Peer-review: Externally peer-reviewed.

Ethics Committee Approval: Ethics committee approval was received for this study from the ethics committee of Cukurova University School of Medicine (21.11.2012, protocol no: 2764).

Informed Consent: Written informed consent was obtained from patients who participated in this study.

\section{Author Contributions}

Concept - H.Y., U.G.; Design - H.Y., V.K.; Supervision - H.Y., A.A.; Funding H.Y., Ş.D.; Materials - O.K.S., M.Ş.T.; Data Collection and/or Processing - Y.G., Ş.D.; Analysis and/or Interpretation - H.Y., V.K.; Literature Review - H.Y.; Writing - H.Y., U.G.; Critical Review - O.K.S., M.Ş.T.

\section{Çıkar Çatışması}

Yazarlar herhangi bir çıkar çatışması bildirmemişlerdir.

Hakem değerlendirmesi: Dış bağımsız.

Etik Komite Onayı: Bu çalışma için etik komite olayı Çukurova Üniversitesi Tıp Fakültesi'nden (21.11.2012, protokol no: 2764) alınmıştır.

Hasta Onamı: Yazılı hasta onamı bu çalışmaya katılan hastalardan alınmıştır.

\section{Yazar Katkıları}

Fikir - H.Y., U.G.; Tasarım - H.Y., V.K.; Denetleme - H.Y., A.A.; Kaynaklar H.Y., Ş.D.; Malzemeler - O.K.S., M.Ş.T.; Veri toplanması ve/veya işlemesi Y.G., S..D.; Analiz ve/veya yorum - H.Y., V.K; Literatür taraması - H.Y.; Yazıyı yazan - H.Y., U.G.; Eleştirel İnceleme - O.K.S., M.Ş.T.

\section{REFERENCES}

1. Reynen K. Cardiac myxomas. N Engl J Med 1995; 333: 1610-17. [CrossRef]

2. Burke A, Virmanir K. Tumors of the heart and the great vessels. In: Rosai j, ed.Atlas of tumor Pathology. Third series, Fascicle 16.Washington,DC: Armed Forced Institute of Pathology; 1996.p.231.

3. Kirklin JW, Barratt-Boyes BG. Cardiac Surgery. 3rd ed. New York: Churchill Livingstone; 2003.p.1679-99.

4. Straus R, Meliss R. Primary tumour of heart. AMA Arch Pathol 1945; 39: 74-9.

5. Reece IJ, Cooley DA, Frazier OH, Hallman GL, Powers PL, Montero CG. Cardiac tumors. Clinical spectrum and prognosis of lesions other than classical benign myxoma in 20 patients. J Thorac Cardiovasc Surg 1984; 88: 439-46.

6. Muthubaskaran V, Anitha S, Chandrasekar P, Muralidharan S. Cardiac myxoma-22 year single center experience. Indian J Thorac Cardiovasc Surg 2010; 26: 239-42. [CrossRef]

7. Sabiston Jr DC, Hattler Jr BG. Tumors of heart. In: Sabiston Jr DC Spencer FC, editors. Surgery of the chest. 4th ed. Philadelphia: WB Saunders; 1983.

8. Obrenovic-Kircanski B, Mikic A, Parapid B, Djukic P, Kanjuh V, Milic $\mathrm{N}$, et al. A 30-year-single- center experience in atrial myxomas: from presentation to treatment and prognosis. Thorac and Cardiovasc Surg 2012; 3. [Epub ahead of print]

9. Miralles A, Bracamonte L, Soncul H, Diaz del Castillo R, Akhtar R, Bors V. Cardiac tumors: clinical experience and surgical results in 74 patients. Ann Thorac Surg 1991; 52: 886-95. [CrossRef]

10. Samanidis G, Perreas K, Kalogris P, Dimitriou S, Balanika M, Amanatidis G. Surgical treatment of primary intracardiac myxoma: 19 years of experience. Interact Cardiovasc Thorac Surg 2011; 13: 597-600. [CrossRef]

11. Cho BK, Lee DY, Pezzella AT, Hong SN, Hong PW. Surgical treatment of atrial myxomas: a report of 20 cases. Tex Heart Inst J 1989; 16: 81-5.

12. DiSesa VJ, Collins JJ, Cohn LH. Considerations in the surgical management of left atrial myxoma. J Card Surg 1988; 33: 15-22. [CrossRef]

13. Kabbani SS, Cooley DA. Atrial myxoma. Surgical considerations. J Thorac Cardiovasc Surg 1973; 65: 731-7.

14. Chitwood WR Jr. Cardiac neoplasms: current diagnosis, pathology and therapy. J Card Surg 1988; 3: 119-54. [CrossRef]

15. Murphy MC, Sweeney MS, Putnam JB Jr, Walker EW, Frazier OH, Ott AD. Surgical treatment of cardiac tumors: a 25-year experience. Ann Thorac Surg 1990; 49: 612-7. [CrossRef]

16. Castells E, Ferran V, Octavio de Toledo MC, Calbet JM, Benito M. Cardiac myxomas: Surgical management, long term results and recurrence. J Cardiovasc Surgery (Torino) 1993; 34: 49-53.

17. Bhan A, Mehrotra R, Chouhary SK, Sharma R, Prabhakar D, Airan B. Surgical experience with intra cardiac myxomas: Long-term followup. Ann Thorac Surg 1998; 66: 810-3. [CrossRef]

18. McCarthy PM, Schaff HV, Winkler HZ, Lieber MM, Carney JA. Deoxyribonucleic acid ploidy pattern of cardiac myxomas. J Thorac Cardiovasc Surg 1989; 98: 1083-6.

19. Gerbode F, Keith WJ, Hill JD. Surgical management of tumors of the heart. Surgery 1967; 61: 94-101.

20. Dang CR, Hurley EJ. Contralateral recurrent myxoma of the heart. Ann Thorac 1976; 21: 59-62. [CrossRef] 